\title{
Effect of Lipopolysaccharide Infusion on Serum Macromineral and Vitamin D Concentrations in Dairy Cows ${ }^{1}$
}

\author{
M. R. Waldron*, B. J. Nonnecke†, T. Nishida*, R. L. Horst†, and T. R. Overton* \\ *Department of Animal Science, Cornell University, Ithaca 14853 \\ †National Animal Disease Center (NADC), USDA.ARS, Ames 50010
}

\begin{abstract}
Four multiparous lactating cows (175 to $220 \mathrm{~d}$ in milk) were used in a $4 \times 4$ Latin square design to assess the effects of four doses $(0.0,0.5,1.0,1.5 \mu \mathrm{g} / \mathrm{kg}$ of body weight) of lipopolysaccharide (LPS; Escherichia coli 0111:B4) on circulating concentrations of macrominerals and vitamin $\mathrm{D}$ metabolites. Treatments were dissolved in $100 \mathrm{ml}$ of sterile saline and infused intravenously over a period of $100 \mathrm{~min}$. Blood was sampled immediately before infusion $(0 \mathrm{~h})$, at 60 -min intervals for $8 \mathrm{~h}$, and at 24 and $48 \mathrm{~h}$ postinfusion. Vitamin D metabolites were analyzed in samples collected at 0,2 , 6,24 , and 48 h only. Serum $\mathrm{Ca}$ and $\mathrm{P}$ concentrations decreased after LPS infusion, but there was no effect on serum magnesium concentration. Plasma $25-\mathrm{OH}$ vitamin $\mathrm{D}_{3}$ and $1,25-(\mathrm{OH})_{2}$ vitamin $\mathrm{D}_{3}$ were not affected by LPS infusion; however, when analyzed as 0 vs. all other doses of LPS combined, there was a tendency for plasma $1,25-(\mathrm{OH})_{2}$ vitamin $\mathrm{D}_{3}$ concentration to decrease when cows were infused with LPS. The inflammatory response elicited by LPS altered plasma macromineral concentrations, a result that may have important implications for calcium homeostasis and metabolic health of lactating dairy cows.
\end{abstract}

(Key words: lipopolysaccharide, minerals, vitamin D)

Abbreviation key: 1,25-( $\mathbf{O H})_{2} \mathbf{D}=1,25$-dihydroxyvitamin $\mathrm{D}_{3}, \mathbf{2 5}$-OHD $=\mathbf{2 5}$-hydroxyvitamin $\mathrm{D}_{3}, \mathbf{P I H}=$ hour after the initiation of infusion, PTH = parathyroid hormone, TNF- $\alpha=$ tumor necrosis factor- $\alpha$.

\section{INTRODUCTION}

The susceptibility of the periparturient dairy cow to infectious disease has been associated with metabolic

Received May 1, 2003.

Accepted June 4, 2003.

Corresponding author: Thomas R. Overton; e-mail: tro2@cornell. edu

${ }^{1}$ Supported in part by the Cornell University Agricultural Experiment Station federal formula funds, project No. 127453 received from Cooperative State Research, Education, and Extension Service, USDA. Any opinions, findings, conclusions, or recommendations expressed in this publication are those of the authors and do not necessarily reflect the view of the USDA. disease (Curtis et al., 1985). Cows with milk fever are 5.4 times more likely to contract clinical mastitis (Curtis et al., 1985), and cows hospitalized with retained placenta are more than 3 times as likely to get mastitis than are cows without retained placenta (Schukken et al., 1989). These findings indicate either that metabolic factors negatively impact immunity or that predisposing factors are responsible for the etiology of both metabolic disorders and infectious disease.

Numerous studies have investigated effects of metabolic variables (i.e., hormones or nutrients) on immune function in dairy cattle. Kehrli and Goff (1989) reported that hypocalcemia does not exacerbate the decreased immune function common in periparturient cows. However, few studies have focused on the effects of immune activation on macromineral metabolism in ruminants. Although reports of decreased serum $\mathrm{Ca}$ and $\mathrm{P}$ concentrations in dairy cattle following immune activation exist in the literature (Griel et al., 1975; Sandstedt et al., 1984), the effects that immune activation may have on macromineral metabolism in lactating dairy cows have not been characterized.

The objective of this study was to characterize the effects of immune activation on aspects of macromineral metabolism in lactating dairy cattle. The primary objective was to determine if intravenous infusion of LPS would affect concentrations of serum $\mathrm{Ca}, \mathrm{P}$, and $\mathrm{Mg}$ in midlactation cows. A secondary objective was to examine associations between macromineral concentrations and circulating concentrations of vitamin D metabolites.

\section{MATERIALS AND METHODS}

\section{Experimental Design}

All infusion and sampling procedures in this experiment were approved by the Cornell University Institutional Animal Care and Use Committee before initiating the experiment. Four multiparous lactating Holstein cows (175 to $220 \mathrm{DIM}$ ) were used in a $4 \times 4$ Latin square design balanced for carryover effect of treatment to assess the effects of four doses $(0.0,0.5,1.0,1.5 \mu \mathrm{g} /$ $\mathrm{kg}$ of BW) of bacterial LPS (Escherichia coli 0111:B4, 
Sigma Chemical Co., St. Louis, MO) on aspects of macromineral metabolism. Cows at the Cornell University Teaching and Research Dairy Farm were housed in tie stalls, moved to metabolism stalls for the infusion period, and milked three times per day throughout the experiment.

\section{Infusions}

The infusion protocol used was modeled after that of Werling et al. (1996) and Steiger et al. (1999), except that LPS-infused animals were not pair-fed with controls. Cows were fitted with bilateral jugular vein catheters $24 \mathrm{~h}$ before infusion began. The catheters were removed after the 24-h sampling time-point after the initiation of infusion (postinfusion hour; PIH). Treatments were dissolved in $100 \mathrm{ml}$ of $0.9 \%$ sterile saline and infused intravenously through a jugular catheter over a period of $100 \mathrm{~min}$. Infusions were administered via a Plum XL infusion pump (Abbot Laboratories, North Chicago, IL) with a $0.2-\mu M$, low-protein binding Sterile Acrodisc 13 in-line filter (Gelman Sciences, Ann Arbor, MI). The LPS dose for a given infusion day was assigned based on average BW for the $3 \mathrm{~d}$ before infusion. All cows were infused on the same infusion days, which were spaced $7 \mathrm{~d}$ apart. Infusions began about 30 min after the second daily milking $(\sim 0930 \mathrm{~h})$, and cows were offered their daily ration on experimental days at the initiation of infusion. Intakes for individual cows were measured at the end of the 8-h sampling period and daily throughout the experiment. Intake and production data are reported in a companion paper for this study (Waldron et al., 2003).

\section{Sampling Protocol}

Blood was sampled immediately before infusion $(0$ $\mathrm{h}$ ), at hourly intervals thereafter through $8 \mathrm{~h}$, and again at 24 and $48 \mathrm{~h}$. During the first $24 \mathrm{~h}$, blood samples $(10 \mathrm{ml}$ each) were collected into nonheparinized tubes via the catheter contra lateral to infusion. Because jugular catheters were removed after the 24-h sampling period, 48-h blood sampling was via the coccygeal vein into nonheparinized vacuum sampling tubes (Becton Dickinson, Franklin Lakes, NJ). Sampled whole blood was initially placed on ice, and then allowed to sit overnight at $4^{\circ} \mathrm{C}$. Coagulated samples were then centrifuged at $2060 \times g$, and serum was harvested. Serum was stored at $-20^{\circ} \mathrm{C}$ for subsequent analyses for mineral and hormone metabolite concentrations.

\section{Analysis of Macrominerals}

Serum calcium concentrations were determined by atomic absorption spectrometry (Perkin-Elmer Corp.,
Norwalk, CT) using the methods of Cali et al. (1973). Briefly, serum samples were prepared and measured in duplicate by diluting $100 \mu \mathrm{l}$ of plasma in $5 \mathrm{ml}$ of $0.1 \%$ lanthanum oxide solution. A combined $\mathrm{Ca}$ and $\mathrm{Mg}$ lamp was used such that serum $\mathrm{Mg}$ concentration was also determined. Plasma $\mathrm{Ca}$ and $\mathrm{Mg}$ concentrations were determined at 422.7 and $185.3 \mathrm{~nm}$, respectively.

Serum phosphorous was measured colorimetrically using procedures modified from Parekh and Jung (1970), as validated in our laboratory. Briefly, serum $(125 \mu \mathrm{l})$ was precipitated by acidification with $1 \mathrm{ml}$ of molybdic-trichloroacetic acid solution. After mixing and allowing to stand for $5 \mathrm{~min}$, this solution was centrifuged $(1000 \times g)$ and $100 \mu \mathrm{l}$ of supernatant was transferred in duplicate to 96-well microplates (Costar, Corning Inc., Acton, MA). Finally, $150 \mu \mathrm{l}$ of $p$-phenylenediamine reagent (prepared by dissolving $1 \mathrm{~g}$ of $p$-phenylenediamine dihydochloride in $100 \mathrm{ml}$ of $5 \% \mathrm{Na}_{2} \mathrm{~S}_{2} \mathrm{O}_{5}$ solution) was added to all wells and the plate was incubated for 20 min at room temperature. Serum phosphorous was determined at a wavelength between 690 and $560 \mathrm{~nm}$ using a Thermo Max tunable microplate reader spectrophotometer (Molecular Devices, Sunnyvale, CA).

Serum 25-hydroxyvitamin $\mathrm{D}_{3}$ (25-OHD) and 1,25dihydroxyvitamin $\mathrm{D}_{3}\left(\mathbf{1 , 2 5}-(\mathbf{O H})_{2} \mathbf{D}\right)$ were quantified by radioimmunoassay using the methods of Hollis et al. (1993 and 1996, respectively). Intra- and interassay coefficients of variation were 9.4 and $10.8 \%$, and 16.2 and $13.1 \%$ for $25-\mathrm{OHD}$ and $1,25-(\mathrm{OH})_{2} \mathrm{D}$, respectively.

\section{Statistical Analyses}

Data were analyzed as a Latin square design with repeated measures using the GLM procedure of SAS (SAS Inst., Inc., Cary, NC) with the appropriate specified error term. Means were adjusted by analysis of covariance using data collected from each cow before LPS or control infusion, and ANOVA was conducted as described above. The experimental unit was the cow and classification variables were cow, period of the Latin square, treatment, and time of sampling. The model statement included cow, period, treatment, the interaction of cow, period and treatment, time, and the interaction of treatment and time. The potential treatment carryover effect for each measured variable during each period of the Latin square was assessed by testing period using the interaction of cow, period, and treatment as the error term (that interaction had $P>$ 0.20 for all variables). The overall effects of treatment and period were also tested using the interaction of cow, period, and treatment as the error term. Linear, quadratic, and cubic effects of LPS treatment for each variable were tested using orthogonal contrasts with 


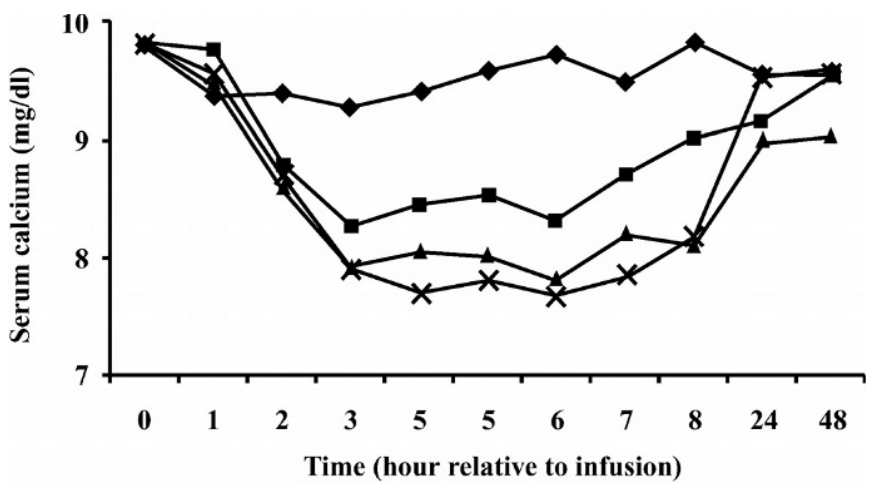

Figure 1. Serum total calcium concentration $(\mathrm{SEM}=0.24) *$ following intravenous infusion of 0.0 (diamond), 0.5 (square), 1.0 (triangle), or 1.5 (X) $\mu \mathrm{g}$ of lipopolysaccharide per kilogram of BW into midlactation dairy cows. Means were adjusted by analysis of covariance. *Treatment $\times$ time effect, $P<0.001$; linear trend, $P=0.08$.

interaction of cow, period, and treatment as the specified error term. Data were also analyzed as all doses of LPS combined vs. saline infusion. These data were analyzed as above except that orthogonal contrasts were not used to test treatment effects. Only analysis of $1,25-(\mathrm{OH})_{2} \mathrm{D}$ yielded different results when analyzed in this manner; therefore, results of analyses for the other metabolites are not shown. Reported means were adjusted means \pm SEM. Significance was declared at $P$ $<0.05$ and trends from $P \geq 0.05$ to $\leq 0.15$.

\section{RESULTS}

Serum total calcium concentration decreased (treatment $\times$ time, $P<0.001$ ) following intravenous LPS administration (Figure 1). There was a trend for serum calcium to be affected in a dose-dependent manner such that increasing amounts of LPS resulted in more severe declines in serum $\mathrm{Ca}$ concentrations (linear trend, $P=$ $0.08)$. Both, the 1.0- and 1.5- $\mu$ g LPS doses resulted in mean serum $\mathrm{Ca}$ concentrations that were considered hypocalcemic $(<8.0 \mathrm{mg} / \mathrm{dl})$. Serum Ca began to decline significantly by $2 \mathrm{~h}$ after the initiation of LPS infusion, reached a nadir by $3 \mathrm{PIH}$, and remained lower than saline-infused cows through $8 \mathrm{PIH}$. Though still lower than controls at $8 \mathrm{PIH}$, serum $\mathrm{Ca}$ began to return to normocalcemic concentrations by $7 \mathrm{PIH}$.

Immune activation resulted in similar longitudinal changes in serum $\mathrm{P}$ concentration. Serum $\mathrm{P}$ concentration decreased dose-dependently (treatment $\times$ time, $P$ $<0.001$; linear effect, $P<0.01$ ) following intravenous LPS administration (Figure 2). Serum P of LPS-infused cows was lower than in saline-infused cows by $2 \mathrm{PIH}$, reached a nadir by $4 \mathrm{PIH}$, and remained lower than saline-infused cows through $8 \mathrm{PIH}$. Though still lower

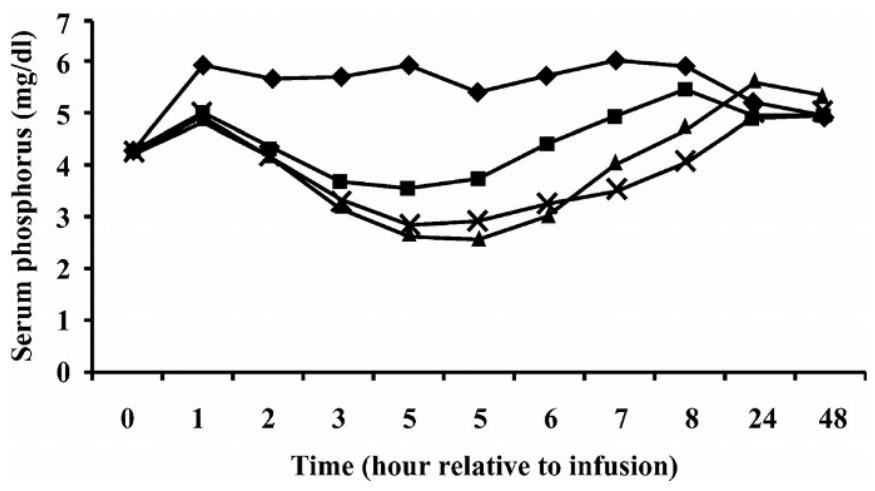

Figure 2. Serum phosphorous concentration (SEM $=0.41) *$ following intravenous infusion of 0.0 (diamond), 0.5 (square), 1.0 (triangle), or $1.5(\mathrm{X}) \mu \mathrm{g}$ of lipopolysaccharide per kilogram of BW into midlactation dairy cows. Means were adjusted by analysis of covariance. *Treatment $\times$ time effect, $P<0.001$; linear effect, $P<0.01$.

than controls at $8 \mathrm{PIH}$, serum $\mathrm{P}$ began to return to normophosphatemic levels by $6 \mathrm{PIH}$.

Serum $\mathrm{Mg}, 25-\mathrm{OHD}$, and 1,25- $(\mathrm{OH})_{2} \mathrm{D}$ concentrations were not altered $(P>0.20)$ following LPS administration (Figures 3, 4, and 5, respectively) when data were analyzed as individual amounts of LPS administered. However, when data were grouped to compare saline vs. all doses of LPS combined, there was tendency (treatment, $P=0.08$ ) for serum concentration of 1,25 $(\mathrm{OH})_{2} \mathrm{D}$ to decrease following immune activation (Figure 6). This tendency for an overall treatment effect for decreased serum $1,25-(\mathrm{OH})_{2} \mathrm{D}$ was mostly the result of decreased serum $1,25-(\mathrm{OH})_{2} \mathrm{D}$ levels at 24 and $48 \mathrm{PIH}$.

\section{DISCUSSION}

The negative effect of immune activation on serum Ca concentration of dairy cattle has been reported pre-

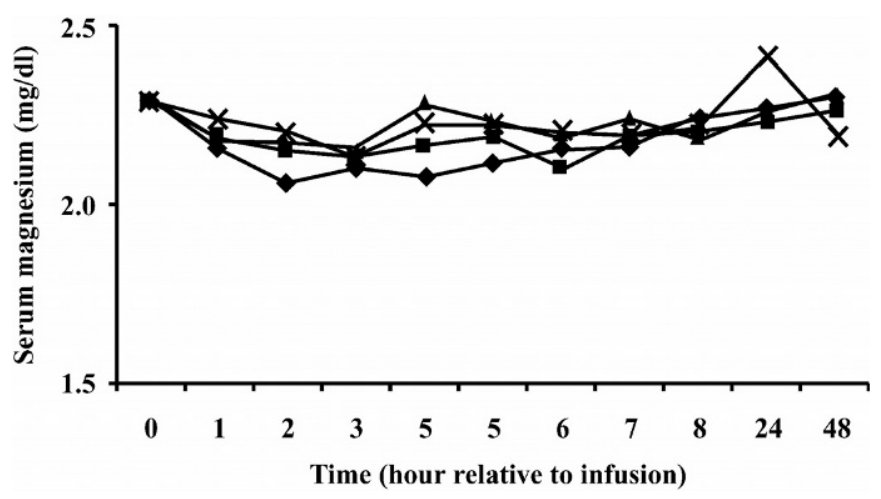

Figure 3. Serum magnesium concentration (SEM $=0.07) *$ following intravenous infusion of 0.0 (diamond), 0.5 (square), 1.0 (triangle), or $1.5(\mathrm{X}) \mu \mathrm{g}$ of lipopolysaccharide per kilogram of $\mathrm{BW}$ into mid lactation dairy cows. Means were adjusted by analysis of covariance. *No treatment effect, $P>0.20$. 


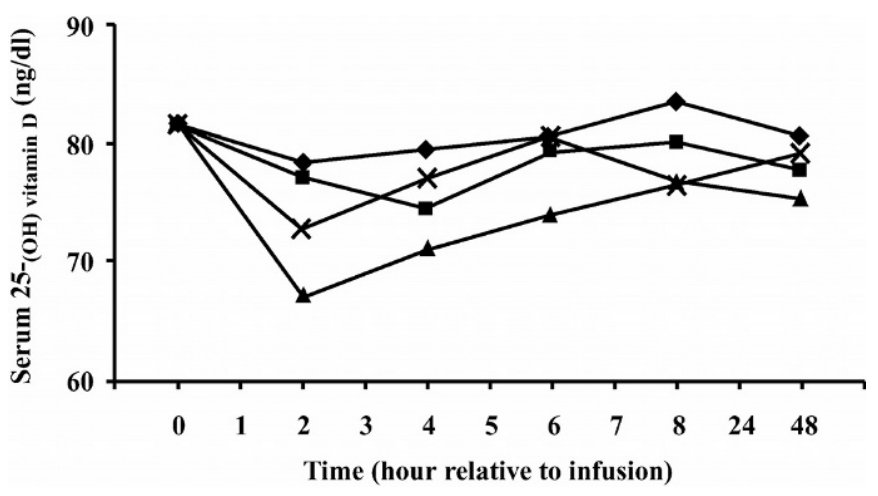

Figure 4. Serum 25- $(\mathrm{OH})$ vitamin $\mathrm{D}$ concentration $(\mathrm{SEM}=4.1)^{*}$ following intravenous infusion of 0.0 (diamond), 0.5 (square), 1.0 (triangle), or $1.5(\mathrm{X}) \mu \mathrm{g}$ of lipopolysaccharide per kilogram of $\mathrm{BW}$ into midlactation dairy cows. Means were adjusted by analysis of covariance. ${ }^{*}$ No treatment effect, $P>0.20$.

viously (Griel et al., 1975; Sandstedt et al., 1984). The current report extends these findings in that the latter study utilized nonlactating cows and activated the immune system via $E$. coli ectotoxin, whereas the former study used infrequent measurements to characterize longitudinal changes following immune activation. Furthermore, our data are consistent with the clinical study of Wenz et al. (2001), who reported decreased serum calcium concentration in cows with moderate to severe coliform mastitis.

Our report of decreased serum phosphorous is also consistent with that of Griel et al. (1975); however, we report a sustained (1 to $7 \mathrm{PIH}$ ) decrease in serum $\mathrm{P}$, whereas the previous study reported decreased $\mathrm{P}$ only at $4 \mathrm{~h}$ after immune activation. Furthermore, despite differences in doses and use of a more crude extract for

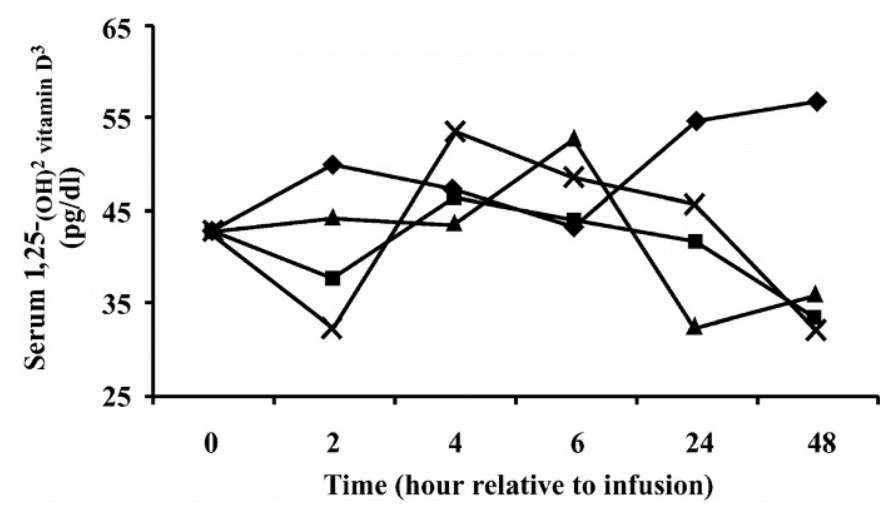

Figure 5. Serum 1,25- $(\mathrm{OH})_{2}$ vitamin $\mathrm{D}_{3}$ concentration $(\mathrm{SEM}=$ 8.3)* following intravenous infusion of 0.0 (diamond), 0.5 (square), 1.0 (triangle), or $1.5(\mathrm{X}) \mu \mathrm{g}$ of lipopolysaccharide per kilogram of BW into midlactation dairy cows. Means were adjusted by analysis of covariance. ${ }^{*}$ No treatment effect, $P>0.20$.

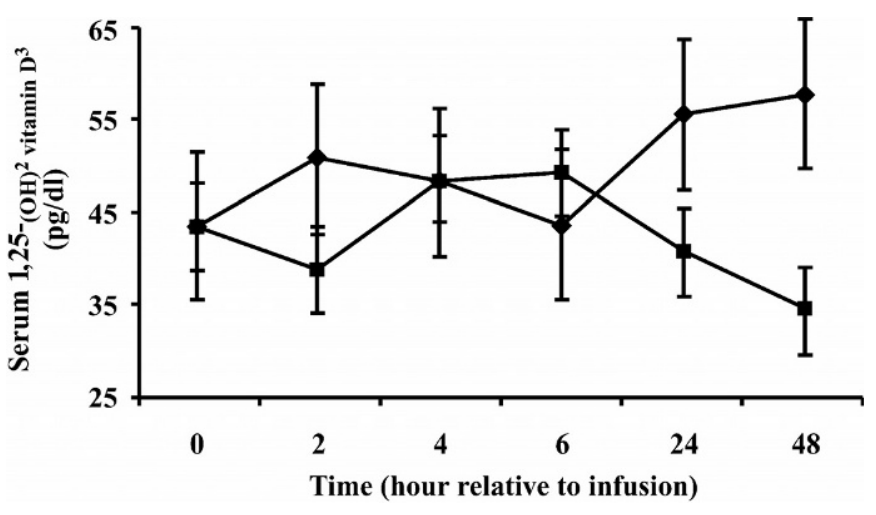

Figure 6. Serum 1,25- $(\mathrm{OH})_{2}$ vitamin $\mathrm{D}_{3}$ concentration $(\mathrm{SEM}=8.0$ and 4.6 for saline and lipopolysaccharide treatments, respectively)* following intravenous infusion of saline $(0.0 \mu \mathrm{g}$ of lipopolysaccharide; diamond) or combined lipopolysaccharide treatment $(0.5,1.0$, or 1.5 $\mu \mathrm{g}$ of lipopolysaccharide per kilogram of BW; square) into midlactation dairy cows. ${ }^{*}$ Treatment trend, $P=0.08$.

immune activation, Sandstedt et al. (1984) reported a magnitude of maximal serum $P$ decrease (40\%) comparable to the current study ( $52 \%$ ).

Few data are available to corroborate the magnesium or vitamin D metabolite data reported in this study. Griel et al. (1975) reported that neither intravenous LPS nor intramammary $E$. coli infection affected serum $\mathrm{Mg}$ concentration of lactating cows. The effect of vitamin D metabolites on aspects of immune function has received some attention (Reinhardt et al., 1999; Ametaj et al., 2000); however, our study is the first to assess the effects of immune activation on vitamin $\mathrm{D}$ status in dairy cattle.

The mechanisms that decreased serum $\mathrm{Ca}$ and $\mathrm{P}$ in this study are unknown. As the primary macromineral store in the body, bone tissue is the target of much homeostatic regulation. Osteoclasts and osteoblasts are transient cells residing at the bone tissue matrix that are responsible for bone resorption and deposition, respectively. Osteoclasts develop from the mononuclear leukocytic cell lineage upon osteotropic hormone (Udagawa et al., 1990) and cytokine stimulation (Jilka, 1998), and proinflammatory cytokines and prostaglandins released during inflammation have been shown to induce bone resorptive activity in several experimental models (Gowen et al., 1990; Chiang et al., 1999; Li et al., 2002). Furthermore, Goff et al. (1991) noted that persistent parathyroid hormone (PTH) stimulation, even during noninflammatory hypocalcemia, causes the release of prostaglandins and the proinflammatory cytokine interleukin- 6 by osteoblasts that activate the osteolytic activity of osteoclasts. These reports indicate that immune-related bone homeostatic mechanisms might result in increased mobilization of $\mathrm{Ca}$ and $\mathrm{P}$ from 
bone. If systemic clearance, intestinal absorption, and cellular/tissue uptake were unchanged, then we might expect hypercalcemia and hyperphosphatemia following immune activation-a hypothesis not consistent with our data. However, the actions of inflammatory mediators at sites of osteoregulatory control other than the bone matrix have been poorly characterized (especially in ruminants) and require further study.

A paucity of information exists to describe the effects of immune activation on macromineral tissue uptake and systemic clearance. However, the total extracellular Ca pool of a $600-\mathrm{kg}$ cow is about 800 -fold greater than the total intracellular Ca pool size (Goff, 1999), therefore it is unlikely that cellular uptake of $\mathrm{Ca}$ was responsible for the decreased serum $\mathrm{Ca}$ in this study. Regarding plasma clearance, few data are available to assess the effects of immune activation on renal macromineral reabsorption or urinary excretion. However, Proksch et al. (1996) reported that Lipid A (the most immunoreactive portion of LPS) stimulation of rat renal proximal tubule cells resulted in inositol-triphosphateinduced changes in intracellular $\mathrm{Ca}$ homeostasis that were similar to those expected to be induced by binding of PTH to its receptor. Although not a direct measure of renal $\mathrm{Ca}$ reabsorption, those findings indicate that immune activation may actually result in enhanced renal $\mathrm{Ca}$ conservation. An additional route of systemic clearance, Lohuis et al. (1988b) cited one report of decreased $\mathrm{Ca}, \mathrm{Mg}$, and phosphate concentrations in mastitic milk from endotoxin-treated mammary glands. Although caution should be used when extrapolating those data to our study conducted using intravenous LPS infusion, they do indicate that immune activation may result in decreased macromineral secretion into the mammary gland. Furthermore, milk secretion in this study was decreased in a dose-dependent manner (by up to 60\%) following LPS infusion, as reported in a companion paper (Waldron et al., 2003). Thus, it is unlikely that the hypocalcemia and hypophosphatemia reported herein were due to increased secretion of these minerals into milk. In summary, speculation from the available data does not support the theory that increased cellular uptake or systemic clearance is responsible for the LPS-induced hypocalcemia or hypophosphatemia reported in our study.

Intravenous LPS infusion also increased plasma cortisol and tumor necrosis factor- $\alpha$ (TNF- $\alpha$ ) concentrations (Waldron et al., 2003), and presumably other proinflammatory cytokines and prostaglandins during this study. Hirsch et al. (1998) reported that under certain conditions in rats, glucocorticoids possess calcitoninlike activity and may act to restrict plasma Ca levels, especially during hypercalcemic events. In dairy cows, Horst and Jorgensen (1982) reported that high cortisol levels (around calving) were at least partly responsible for periparturient hypophosphatemia. Also, the administration of proinflammatory cytokines results in hypocalcemia (Boyce et al., 1989) and hypophosphatemia (Barak et al., 1998) in laboratory animals. Evidence from the former authors indicates that those effects may be mediated via calcitonin-like effects of prostaglandins. The increase in plasma cortisol and proinflammatory cytokine concentrations following immune activation may have contributed to the hypocalcemia and hypophosphatemia reported in the current study.

Vitamin D has been shown to exhibit immunoregulatory activity in several cell types (Hustmyer et al., 1994; Ametaj et al., 1996; Nonnecke et al., 2003) and immune activation reportedly caused leukocytic vitamin D production and upregulation of vitamin $D$ receptors in various in vitro and in vivo experimental systems (Reinhardt and Hustmyer, 1987). Therefore, although circulating concentrations of vitamin D metabolites were minimally affected by immune activation, it is possible that alterations of vitamin $\mathrm{D}$ activity in specific inflammatory microenvironments occurred in this study and may have affected macromineral homeostatic regulation. Furthermore, although circulating concentrations of regulatory hormones yield some information about macromineral homeostasis, these data alone may be insufficient to elucidate the mechanisms of macromineral dysregulation. For example, plasma concentrations of PTH (Mayer et al., 1969) and 1,25-OHD (Horst et al., 1978) are actually elevated, whereas plasma calcitonin concentration is decreased (Mayer et al., 1975) immediately preceding and during most cases of hypocalcemic parturient paresis in dairy cows. Thus, factors (other than hormone concentrations) at the tissue level, such as receptor numbers, binding affinity, hormone clearance, and postreceptor signaling may also be affected during cases of macromineral dysregulation (Horst et al., 1994).

Concerning traditional osteoregulatory hormones, if serum concentrations of PTH and $1,25-(\mathrm{OH})_{2} \mathrm{D}$ were acutely decreased by immune activation, it may be unlikely that decreases in these hormones would have resulted in the lower serum calcium concentrations reported in this study. Horst et al. (1994) reported that $24 \mathrm{~h}$ was required for $1,25-(\mathrm{OH})_{2} \mathrm{D}$ to upregulate $\mathrm{Ca}$ absorption from the gut, and $48 \mathrm{~h}$ was required for PTHstimulated bone resorption to be initiated; however, the time required for down regulation of those processes was not studied. Serum Ca concentrations were decreased significantly by $2 \mathrm{~h}$ after the initiation of LPS infusion in the current study. Therefore, if macromineral entry rate is decreased following immune activation, it is unlikely to be via traditional homeostatic 
mechanisms, and other more acute changes must occur to affect $\mathrm{Ca}$ homeostasis.

A final possible mechanism that should be explored in the etiology of immune-related hypocalcemia and hypophosphatemia is the possibility of decreased absorption across the gastrointestinal tract. Decreased absorption could be the result of decreased feed intake, gut stasis, or sympathetic neural influences that directly or indirectly affect macromineral transfer across the intestine. It is possible that decreased feed intake, as reported in a companion paper (Waldron et al., 2003), contributed to the lower concentrations of serum $\mathrm{Ca}$ and $\mathrm{P}$ reported in the current study. However, serum $\mathrm{Ca}$ and $\mathrm{P}$ concentrations were significantly decreased by 2 and $1 \mathrm{PIH}$, respectively, and because the expected effects of feed intake on serum variables is expected to be less acute in ruminants (see discussion in Waldron et al., 2003), it is unlikely that changes in feed intake were solely responsible for the decreased serum $\mathrm{Ca}$ and $P$ reported herein. Boosman et al. (1990) reported that intravenous LPS infusion into lactating cattle resulted in a rapid increase (within 3 to $15 \mathrm{~min}$ ) in circulating concentrations of norepinephrine. Furthermore, administration of LPS is widely recognized to decrease recticulo-rumen motility. Details of the gastrointestinal effects of LPS administration were reviewed by Lohuis et al. (1988a). The rapid onset of decreased gut motility (within $30 \mathrm{~min}$ ) makes it an attractive potential mechanism for decreased macromineral entry into systemic circulation.

The implications of decreased circulating $\mathrm{Ca}$ and $\mathrm{P}$ concentrations reported in this study indicate that tissue stores of these minerals might also be depleted following immune activation. Daniel (1983) reported that experimental hypocalcemia of the magnitude reported herein decreased abomasal motility and contractile strength by 70 and 50\%, respectively. Furthermore, proinflammatory cytokines, such as TNF- $\alpha$, also decrease the contractility of skeletal muscle in laboratory animals (Reid et al., 2002). Speculatively, muscular tone of tissues such as the uterus and abomasum may be negatively affected by suboptimal Ca concentrations and the direct effects of proinflammatory cytokines following immune activation. These mechanisms should be investigated in lactating dairy cows considering the increased incidence of retained placenta and displaced abomasum that can accompany infectious disease (Curtis et al., 1985; Schukken et al., 1989).

\section{CONCLUSIONS}

Immune activation via intravenous LPS administration resulted in decreased circulating concentrations of serum $\mathrm{Ca}$ and $\mathrm{P}$ in midlactaion dairy cows. Serum concentrations of $\mathrm{Mg}, 25-\mathrm{OHD}$, and $1,25-(\mathrm{OH})_{2} \mathrm{D}$ were largely unaffected by immune activation. The cause of the hypocalcemia and hypophosphatemia following immune activation is unclear and requires further investigation. However, decreased serum $\mathrm{Ca}$ and $\mathrm{P}$ following immune activation may indicate a causative mechanism whereby immune activation increases the risk of secondary metabolic disorders such as retained placenta, displaced abomasum, and milk fever. Further mechanistic research of macromineral metabolism following immune activation in lactating cows is warranted.

\section{ACKNOWLEDGMENTS}

The authors thank D. Hoy and C. Hauber of the NADC, ARS, USDA for excellent technical support.

\section{REFERENCES}

Ametaj, B. N., D. C. Beitz, T. A. Reinhardt, and B. J. Nonnecke. 1996. 1,25-Dihydroxyvitamin $\mathrm{D}_{3}$ inhibits secretion of interferon- $\gamma$ by mitogen- and antigen-stimulated bovine mononuclear leukocytes. Vet. Immunol. Immunopathol. 52:77-90.

Ametaj, B. N., B. J. Nonnecke, R. L. Horst, and D. C. Beitz. 2000. Effects of retinoic acid and 1,25-dihydroxyvitamin $\mathrm{D}_{3}$ on IFN- $\gamma$ secretion by mononuclear leukocytes from nulliparous and postparturient dairy cattle. Int. J. Vitam. Nutr. Res. 70:92-101.

Barak, V., A. Schwartz, I. Kalickman, B. Nisman, G. Gurman, and Y. Shoenfeld. 1998. Prevelence of hypophosphatemia in sepsis and infection: The role of cytokines. Am. J. Med. 104:40-47.

Boosman, R., C. W. Mutsaers, and S. J. Dieleman. 1990. Sympathetico-adrenal effects of endotoxemia in cattle. Vet. Rec. 127:11-14.

Boyce, B. F., A. J. Yates, and G. R. Mundy. 1989. Bolus injections of recombinant human interleukin-1 cause transient hypocalcemia in normal mice. Endocrinology 125:2780-2783.

Cali, J. P., G. N. Bowers, Jr., and D. S. Young. 1973. A referee method for the determination of total calcium in serum. Clin. Chem. 19:1208-1213.

Chiang, C., G. Kyritsis, D. T. Graves, and S. Amar. 1999. Interleukin1 and tumor necrosis factor activities partially account for calvarial bone resorption induced by local injection of lipopolysaccharide. Infect. Immunol. 67:4231-4236.

Curtis, C. R., H. N. Erb, C. J. Sniffen, R. D. Smith, and D. S. Kronfeld. 1985. Path analysis of dry period nutrition, postpartum metabolic and reproductive disorders, and mastitis in Holstein cows. J. Dairy Sci. 68:2347-2360.

Daniel, R. C. 1983. Motility of rumen and abomasum during hypocalcaemia. Can. J. Comp. Med. 47:276-280.

Goff, J. P. 1999. Treatment of calcium, phosphorus, and magnesium balance disorders. Vet. Clin. N. Am. Food Anim. Pract. 15:619639.

Goff, J. P., T. A. Reinhardt, and R. L. Horst. 1991. Enzymes and factors controlling vitamin D metabolism and action in normal and milk fever cows. J. Dairy Sci. 74:4022-4032.

Gowen, M., K. Chapman, A. Littlewood, D. Hughes, D. Evans, and G. Russell. 1990. Production of tumor necrosis factor by human osteoblasts is modulated by other cytokines, but not by osteotropic hormones. Endocrinology 126:1250-1255.

Griel, Jr., L. C., A. Zarkower, and R. J. Eberhart. 1975. Clinical and clinico-pathological effects of Escherichia coli endotoxin in mature cattle. Can. J. Comp. Med. 39:1-6.

Hirsch, P. F., Y. Imai, Y. Hosoya, H. Ode, and S. Maeda. 1998. Glucocorticoids possess calcitonin-like antihypercalcemic properties in rats. Endocrine 8:29-36. 
Hollis, B. W., J. Q. Kamerud, A. Kurkowski, J. Beaulieu, and J. L. Napoli. 1996. Quantification of circulating 1,25-dihydroxyvitamin $\mathrm{D}$ by radioimmunoassay with an ${ }^{125}$ I-labeled tracer. Clin. Chem. 42:586-592

Hollis, B. W., J. Q. Kamerud, S. R. Selvaag, J. D. Lorenz, and J. L. Napoli. 1993. Determination of vitamin D status by radioimmunoassay with an ${ }^{125}$ I-labeled tracer. Clin. Chem. 39:529-533.

Horst, R. L., J. P. Goff, and T. A. Reinhardt. 1994. Calcium and vitamin D metabolism in the dairy cow. J. Dairy Sci. 77:19361951.

Horst, R. L., and N. A. Jorgensen. 1982. Elevated plasma cortisol during induced and spontaneous hypocalcemia in ruminants. J. Dairy Sci. 65:2332-2337.

Horst, R. L., N. A. Jorgensen, and H. F. DeLuca. 1978. Plasma 1,25dihydroxyvitamin D and parathyroid hormone levels in paretic dairy cows. Am. J. Physiol. 235:E634-E637.

Hustmyer, F. G., D. C. Beitz, J. P. Goff, B. J. Nonnecke, R. L. Horst, and T. A. Reinhardt. 1994. Effects of in vivo administration of 1,25-dihydroxyvitamin $\mathrm{D}_{3}$ on in vitro proliferation of bovine lymphocytes. J. Dairy Sci. 77:3324-3330.

Jilka, R. L. 1998. Cytokines, bone remodeling, and estrogen deficiency: A 1998 update. Bone 23:75-81.

Kehrli, M. E., Jr., and J. P. Goff. 1989. Periparturient hypocalcemia in cows: Effects on peripheral blood neutrophil and lymphocyte function. J. Dairy Sci. 72:1188-1196.

Li, L., A. Khansari, L. Shapira, D. T. Graves, and S. Amar. 2002. Contribution of interleukin-11 and prostaglandin(s) in lipopolysaccharide-induced bone resorption in vivo. Infect. Immun. 70:3915-3922.

Lohuis, J. A., J. H. Verheijden, C. Burvenich, and A. S. van Miert. 1988a. Pathophysiological effects of endotoxins in ruminants: 1. Changes in body temerature and reticulo-rumen motility, and the effect of repeated administration. Vet. Q. 10:109-116.

Lohuis, J. A., J. H. Verheijden, C. Burvenich, and A. S. van Miert. 1988b. Pathophysiological effects of endotoxins in ruminants: 2. Metabolic aspects. Vet. Q. 10:117-125.

Mayer, G. P., J. W. Blum, and L. J. Deftos. 1975. Diminished prepartal plasma calcitonin concentration in cows developing parturient hypocalcemia. Endocrinology 96:1478-1485.

Mayer, G. P., C. F. Ramberg, D. S. Kronfeld, R. M. Buckle, L. M. Sherwood, G. D. Aurbach, and J. T. Potts, Jr. 1969. Plasma parathyroid hormone concentration in hypocalcemic parturient cows. Am. J. Vet. Res. 30:1587-1597.

Nonnecke, B. J., W. R. Waters, M. R. Foote, R. L. Horst, M. A. Fowler, and B. L. Miller. 2003. In vitro effects of 1,25-dihydroxyvitamin
$\mathrm{D}_{3}$ on interferon- $\gamma$ and tumor necrosis factor- $\alpha$ secretion by blood leukocytes from young and adult cattle vaccinated with Mycobacterium bovis BCG. Int. J. Nutr. Res. 73:235-244.

Parekh, A. C., and D. H. Jung. 1970. Serum inorganic phosphorus determination using p-phenylenediamine as a reducing agent. Clin. Chim. Acta 27:373-377.

Proksch, J. W., L. A. Traylor, and P. R. Mayeux. 1996. Effects of Lipid A on calcium homeostasis in renal proximal tubules. J. Pharmacol. Exp. Ther. 276:555-560.

Reid, M. B., J. Lannergren, and H. Westerblad. 2002. Respiratory and limb muscle weakness induced by tumor necrosis factor- $\alpha$ : involvement of muscle myofilaments. Am. J. Respir. Crit. Care Med. 166:479-484.

Reinhardt, T. A., and F. G. Hustmyer. 1987. Role of vitamin D in the immune system. J. Dairy Sci. 70:952-962.

Reinhardt, T. A., J. R. Stabel, and J. P. Goff. 1999. 1,25-Dihydroxyvitamin $\mathrm{D}_{3}$ enhances milk antibody titers to Escherichia coli J5 vaccine. J. Dairy Sci. 82:1904-1909.

Sandstedt, H., L. Larsson, and C. Kvart. 1984. Effect of $E$. coli ectotoxin on calcium and phosphate concentration in serum of dairy cows. Nord. Vet. Med. 36:406-407.

Schukken Y. H., H. N. Erb, and J. M. Scarlett. 1989. A hospitalbased study of the relationship between retained placenta and mastitis in dairy cows. Cornell Vet. 79:319-326.

Steiger, M., M. Senn, G. Altreuther, D. Werling, F. Sutter, M. Kreuzer, and W. Langhans. 1999. Effect of a prolonged low-dose lipopolysaccharide infusion on feed intake and metabolism in heifers. J. Anim. Sci. 77:2523-2532.

Udagawa, N., N. Takahashi, T. Akatsu, H. Tanaka, T. Sasaki, T. Nishihara, T. Koga, T. J. Martin, and T. Suda. 1990. Origin of osteoclasts: Mature monocytes and macrophages are capable of differentiating into osteoclasts under a suitable microenvironment prepared by bone marrow-derived stromal cells. Proc. Natl. Acad. Sci. 87:7260-7264

Waldron, M. R., T. Nishida, B. J. Nonnecke, and T. R. Overton. 2003. Effect of lipopolysaccharide on indices of peripheral and hepatic metabolism in lactating cows. J. Dairy Sci. 86:3447-3459.

Wenz, J. R., G. M. Barrington, F. B. Garry, R. P. Dinsmore, and R. J. Callan. 2001. Use of systemic disease signs to assess disease severity in dairy cows with acute coliform mastitis. J. Am. Vet. Med. Assoc. 218:567-572.

Werling, D., F. Sutter, M. Arnold, G. Kun, P. C. J. Tooten, E. Gruys, M. Kreuzer, and W. Langhans. 1996. Characterisation of the acute phase response of heifers to a prolonged low dose infusion of lipopolysaccharide. Res. Vet. Sci. 66:252-257. 